\title{
Antecipar o "Apagar das Luzes"? \\ Religião, Arte, Subjetividade e Sociedade no Conto "0 artista da fome" (Ein Hungerkünstler) de Franz Kafka
}

\author{
To anticipate the "Extinguishing candles"? \\ Religion, art, subjectivity and society in the Franz Kafka's \\ novel "The hunger artist” (Ein Hungerkünstler)
}

\section{Manoel Ribeiro de Moraes Junior*}

Universidade Estadual do Pará, Belém, PA, Brasil

\section{Resumo}

Este trabalho não procura enquadrar o conto 0 Artista da Fome de Franz Kafka às categorias teóricas da filosofia ou da teologia, muito menos subjuga-la às interpretações das Ciências da Religião. Menos que isto, este trabalho procura colher pistas de expressões humanas à luz de aspectos culturais que entendem-se ser religioso e teológico, porém, com compromisso maior de compreender e explicar a densidade do humano que, por sua vez, se mostra melhor no palco principal de sua mais importante revelação: a narrativa como tessitura exposta e significada da auto-compreensão humana sobre seus mundos físico, social e subjetivo. Na primeira parte deste artigo, procuraremos destacar os aspectos do imaginário judaico e social no qual circunscreviam

MRMJ: Doutor em Ciências da Religião, e-mail: manoelribeiromoraesjґ@gmail.com 
comportamentos da época de Franz Kafka. Na parte seguinte, trataremos do Artista da Fome. Um personagem que revela a tensão entre o "viver humano", a fome e a indiferença por meio dos serviços de empregabilidade alienante e da sociabilidade posta sem afetividade. Na última parte, será exposta uma dimensão sobre a antropologia reprimida em tempos de prevalência de imperativos desenvolvimentistas, mas que é fundamental para os ideais de política democrática e estofo para qualquer sociedade que se permita à tensão equiparada entre liberdade e justiça. A hipótese deste trabalho aponta para o fato de que a supressão da autonomia humana é abertura para tempos terminais da história e da política.

Palavras-chave: Literatura. Estética. Religião. Emancipação. Crítica.

\section{Abstract}

This paper theoretically studies the short story "The Hunger Artist" by Franz Kafka, in the Science of Religion. This work seeks to reap lanes human expressions in the light of cultural aspects that understand themselves to be religious and theological, but with greater commitment to understand and explain the human density that, in turn, shows on the main stage of their most important revelation: the narrative as exposed fabric and signified of human self-understanding of their physical, social and subjective worlds. In the first part of this article, we seek to emphasize the aspects of Jewish and social imaginary in which circumscribed behaviors from the time of Franz Kafka. In the next part, we will treat the Hunger Artist. A character that reveals the tension between the "living human" hunger and indifference by means of alienating employability and sociability called without affectivity services. In the last part, it will expose a dimension of the repressed in times of prevalence of developmental imperatives, but is fundamental to the ideals of democratic politics and padding to any society that allows the tension between liberty and justice equated anthropology. The hypothesis of this work points to the fact that the suppression of human autonomy is the opening times of terminals for history and politics.

Keyworks: Literature. Estetic. Religion. Emacipation. Critic. 
De um homem que havia feito do mistério, do exílio, do sofrimento, da comoção, maneiras de buscar a Deus e, simultaneamente, maneiras de perdê-lo.

Um homem frágil, pleno de perplexidades, de ambivalências inevitáveis. De encontros sempre adiados, de um "sim é não" que procurava o absoluto no tempo religiosamente fugaz de um acorde, ou de um beijo, ou de uma transitória libertação fantasmagórica. Mesmo se a libertação não chegasse, eu queria ser sempre digno dela, escreveu Franz Kafka, tão irmão de Mahler em muitas questões intimas. Essa libertação, acorde ou beijo, é a que buscamos em meio à condenação e às impotências. Essa morte que faz de um herói um simples mortal, esse exílio que faz do mortal um estranho, esse mistério que faz da nossa estranheza uma justificação sempre penúltima, esse estremecimento que faz dos acordes ou beijos efêmeros fantasmas, tudo isso fez de Mahler um homem, uma humanidade antecipatória. (Arnoldo Liberman escrevendo sobre Mahler sob referências inclusive de Franz Kafka)

\section{Introdução}

Este artigo se desdobra na riquíssima área do diálogo entre Filosofia e Ciências da Religião que, em cooperação, estudam as expressões socioculturais da Religião. Contudo, a metodologia de pesquisa é alçada interdisciplinarmente para se compreender a dimensão elementar da antropologia política nas teias de um establishment socialmente abrangente. No ocidente, uma das expressões de establishment é a modernidade: a novidade contínua de uma sociedade racionalmente autônoma e que se 
julga capaz de exorcizar continuamente as negatividades que ameaçariam o progresso e a unidade social. Contudo, as expressões do iluminismo e as expectativas para com a sua potencialidade de emancipação social, mais especificamente na Europa Ocidental, decaíram diante das consequências de um ordenamento social consolidado num intenso processo de industrialização e mercantilização, além das guerras tecnologicamente impulsionadas para a destruição do outro humano. Assim, as experiências singulares se contrastaram com as ideologias autoritárias de Estado e dos intelectuais tradicionais. No trânsito entre o século XIX e XX, o definhamento das experiências existenciais não encontravam mais ecos concordantes e cooperativos para com as ideologias majoritárias do Estado absoluto e o ordenamento econômico social vigente. A tensão se expôs no início do século XX: de um lado, a sociedade que busca a sua emancipação, do outro, o Estado e o ordenamento em extratos sociais justaposto pelos privilégios de poder econômico e político de poucos.

$\mathrm{Na}$ primeira, segunda e terceira parte deste artigo, procuraremos destacar os aspectos da dinâmica estético-criativo e do imaginário judaico religioso e social no qual circunscreviam comportamentos intelectuais da época de Franz Kafka. Na quarta parte trataremos do Artista da Fome. Um personagem que revela a tensão entre o "viver humano", a fome e a indiferença por meio dos serviços de empregabilidade alienante e da sociabilidade posta sem afetividade. Neste artigo se exporá uma dimensão sobre a antropologia reprimida em tempos de prevalência de imperativos desenvolvimentistas, mas que é fundamental para os ideais de política democrática e estofo para qualquer sociedade que se permita à tensão equiparada entre liberdade e justiça. A hipótese deste trabalho aponta para o fato de que a supressão da autonomia humana é abertura para tempos terminais da história e da política

Este artigo não procura enquadrar o conto O Artista da Fome de Franz Kafka às categorias teóricas da filosofia ou da teologia, muito menos subjuga-la às interpretações das Ciências da Religião. Menos. Este trabalho procura colher pistas de expressões humanas à luz de aspectos culturais que entende-se ser religioso e teológico, porém, com compromisso maior de compreender e explicar a densidade do humano que, por sua vez, se mostra no palco principal de sua mais importante revelação: 
a narrativa como tessitura exposta e significada da autocompreensão humana sobre seus mundos físico, social e subjetivo.

\section{Aspectos Teóricos Preliminares à Leitura das Obras Franz Kafka}

Considerando a psicanálise freudiana e a filosofia hegeliana do Espírito, as expressões e as institucionalizações sócio culturais provenientes da capacidade humana de significação, narração, memória, comunicação linguística, ordenamento coletivo e tecnológico produtivo, circunscrita a um contexto específico de ambiente e socialização, passaram a ser entendidas teoricamente como fundamentais, mesmo que não absolutas, para a constituição da personalidade, da cultura e de uma forma ou tipo de convívio intersubjetivo. Nesta manifestação dada a partir do tríptico da socialização, a saber, a hominização das expressões e organizações sociais, a institucionalidade do convívio e a sociocultualização dos seres humanos, sempre considerando os ambientes específicos de vivência, pode-se percorrer e entender o papel ativo de várias expressões ou esferas socioculturais e, mais especificamente, para este estudo, o da criação artista e sua dimensão criação-aprendizado na contínua dinâmica de tecimento das cosmovisões, da humanidade e de suas emancipações.

As contribuições de Georg Wilhelm Friedrich Hegel e Sigmund Freud para as ciências humanas foram as de pensar um saber teórico que fosse capaz de compreender e explicar a capacidade de significação, além de outras ações humanas, como o processo simbiótico entre a mente (cultura e personalidade), a história sócio-cultural e a complexidade biológica do corpo humano ${ }^{1}$. Nos tempos de Immanuel Kant, o processo de redução conceitual da filosofia delimitou as discussões antropológicas, teóricas e práticas, aos aspectos puros e transcendentais do pensamento (Anthropologie des reinen Denkens). Por caminhos mais abrangentes e com inclusão dos debates e teses dos ideólogos alemães

Sobre esse tema, não se pode deixar de destacar a obra de Paul-Laurent Assoun, "Freud e as ciências Sociais. Psicanálise e teoria da cultura" (2012), de Perter Gay, "Freud: Uma vida para nosso tempo (2012) e Karl Mannheim “Sociologia do Espírito” (2014). 
entre séculos XVIII ao XIX, os estudos da psicanálise e da cultura alargaram as possíveis percepções, compreensões e interpretações das ações e dos pensamentos humanos, a partir de seus fatos bio-culturais e das suas existências históricas e experimentais.

Relevando os muitos avanços nas ciências e nos estudos filosóficos sobre o ser humano entre os séculos XIX e XXI, o olhar dos estudos socioculturais e, mais especificamente, aqueles focados na antropologia, avançou para além dos modos reflexivos de molduras solipsistas e exclusivamente transcendentais. Tal amplitude tornou possível uma compreensão às ciências humanas mais alargada sobre a formação (Bildung), o pensamento (Denken) e a ação (Handeln) dos seres humanos, inclusive, considerando seus processos de personalização sob múltiplos contextos e diversas possibilidades de experiências sócio culturais. Nessa dinâmica de socialização e hominização, a arte é uma das esferas culturais fundamental para o processo de culturalização e hominização.

Para Sigmund Freud, a arte pode ter a seguinte compreensão:

Um tipo diferente de satisfação é concedido aos participantes de uma unidade cultural pela arte, embora, via de regra, ela permaneça inacessível às massas, que se acham empenhadas num trabalho exaustivo, além de não terem desfrutado de qualquer educação pessoal. Como já descobrimos a muito tempo, a arte oferece satisfações substantivas para as mais antigas e mais profundamente sentidas renuncias culturais, e, por esse motivo, ela serve, como nenhuma outra coisa, para reconciliar o homem com os sacrifícios que tem de fazer em benefício da civilização. Por outro lado, as criações de arte elevam seus sentimentos de identificação, de que toda a unidade cultural carece tanto, proporcionando uma ocasião para a partilha de experiências emocionais altamente valorizadas (FREUD, 2010, p. 23).

Com esta afirmação, Freud apresenta uma ideia sobre a arte e seu papel social. Sob o fio condutor de suas ideias, a arte se manifesta ultimamente na condição de uma práxis regulatória da sociedade e com a finalidade de provocar satisfações substitutas às sensações ou ações interditáveis pelo necessário processo civilizatório. Ora, a agregação social implica arduamente na regulação intersubjetiva das livres vontades e pulsões que cada humano desprende em favor da dinâmica natural e não-axiológica 
do seu metabolismo. As normas de interdição são aquelas impostas às condutas humanas, àqueles e àquelas circunscritos a uma certa agregação, a fim de garantir uma forma de ordenação. Essa hipotética ordenação social implicaria necessariamente na supressão ou no controle de alguns desejos e ações que ameaçassem o modo específico de agregação. A regulação desses impulsos, desejos ou ações reprimíveis, garantiriam a ordem, mas, por outro lado, provocariam mal-estares biopsíquicos entre todas aquelas e aqueles sujeitos às normas. Desta forma, para Freud, as artes seriam expressões de uma "humanidade mental" que consolidariam o status quo de um grupo humano, atenuando as tensões consequentes às propensões flexíveis de sentimentos e condutas que desiquilibrassem as ações interpessoais civilizáveis.

Sem criticar por total a interpretação da interdição na socialização e de seus consequentes mal-estares, é importante se estabelecer certa melhoria nesta tese freudiana, sobretudo, aprofundando a compreensão do papel social desempenhado pela arte no processo de qualquer dinâmica cultural. Primeiro, Sigmund Freud ainda imagina a (verdadeira) arte confinada ao contexto da aristocracia nas sociedades tradicionais ou à burguesia europeia - a sua herdeira no ocidente. É uma restrição do conceito de arte que foi alçada na modernidade iluminista à mercê dos ideais aristocráticos de arte: o belo está circunscrito ao epicentro ordenador de uma sociedade. Porém, é possível concluir que a arte e muitas expressões culturais não estão restritas às forças ordenadoras ou controladoras de grupo político, inclusive, aqueles economicamente mais fortes de uma sociedade. O exemplo histórico mais marcante são as artes dionisíacas na Grécia antiga - aquelas que deram origem à arte da tragédia: elas tencionavam com as expressões apolínias de arte e festa, e, nos primórdios do classicismo grego, tinham maior vigor nas periferias das polis. Por mais que existam mulheres e homens confinados às zonas periféricas de uma sociedade e lá estejam obrigados ao mais fardo, contínuo e mais intenso trabalho - por conta do modo de produção intenso e da acumulação de riqueza que uma sociedade possa expressar em sua ordenação socioeconômica - o processo de criação e expressão artística nunca deixou de se manifestar. A marginalidade estratificada por consequência de uma 
forma de acumulação econômico-social não dita a aparição ou não da expressão artística. Por isso, afirma Vernant que

o dionisíaco não representa de forma alguma um elemento exterior, marginalizado, na civilização grega. Ao contrário, trata-se de um elemento central mas que, dentro do sistema, caminha numa direção diferente. Creio que não exista nenhuma civilização perfeitamente coerente, cuja a lógica possua uma única dimensão. Sim, o Dionísio caminha na contramão de algumas coisas, mas isto também faz parte do sistema (VERNANT, p. 348).

Segundo, a arte não se interpõe só como uma substituição sócio-reconciliadora àqueles prazeres interditáveis pelos processos civilizatórios. Mais do que isso, as expressões estéticas sugam as pulsões vividas por uma força de reinvenção expresso-significativa que nasce a partir de um ato anamnésicos entre memória significada, imanência experimentada e a práxis criativa que, em conjunto, se expressam linguisticamente sempre em novas ordens semânticas, em expressões socializáveis: a arte é um processo de criação e aprendizado em dinâmica. Esta força de criação, a poiesis, busca significar e resignificar tudo o que perpassa pelo metabolismo no qual a consciência humana está enraizada, neuro-vegetada.

Considerando estas duas ideias sobre a arte, pode-se considerar que pelas dimensões poéticas - conceito entendido não como simples aspecto de gênero literário, mas da força criativa da linguagem na revelação significativa do mundo aos humanos — as pulsões vividas não desvanecem e nem são violentamente substituídas, mas ganham continuamente presença simbólica e semântica nos contextos das culturas de forma criativa, em contínuo processo de criação e aprendizado. A arte não é uma simples compensação sensitiva de tudo que seja civilizatório em detrimento do absurdamente não civilizatório. A esfera cultural da arte é aquela que acolhe linguístico e historicamente as sensações experienciais dos homens e das mulheres num contínuo e dinâmico ato de assimilação do que ainda não lhes foram permitidos, significados, aceitos, compreendidos e até mesmo vividos. 


\section{Do Sublime: criação artística e as possibilidades abertas no processo de aprendizagem e crítica para a emancipação humana}

Sobre a dinâmica de criação e narração artística, Walter Benjamin discorda amplamente dos conceitos de ação, percepção e decisão, unilateralmente propostas pelas psicologias naturalistas e fenomenologias formalistas. Para estas ciências da mente criticadas por Walter Benjamin, o universo do ser humano está originalmente disposto num mundo de ações a partir de vivências (erlebens) nuas e cruas e, ainda mais, pré-estabelecidas por um sistema de ordenação conceitual muito próximo àqueles que perfazem aos sistemas estruturados pelas ciências lógico-dedutivas. Diferentemente do que se pensava, na psicologia formalista há uma estrutura de vivência e ordenamento do humano para os atos de conhecimento, ação e interação consigo, com o mundo natural e com seu alter ego. Para Walter Benjamin, o ser humano decide, conhece e interage por experiências (erfahrung) significadas e aprendidas histórico e narrativamente. Para o pensador frankfurtiano, toda ação humana é sempre uma ação simbólica - por isso, cultural, histórica, social, significativa, interativamente.

Em seu texto O Narrador (BENJAMIN, 1994, p. 195-206), Benjamin mostra como a comunicação jornalista baseada na informação unilateral precarizou a capacidade de compreensão do mundo. Isso porque a informação destituiu o ouvinte da participação psicológica na decisão daquilo que foi informado, de ampliação do que foi ouvido, de socialização participativa do que foi anunciado. Entremeios a esta decadência da ação, da narração, da vida, as obras de Franz Kafka persuadem o seu leitor a resgatar a alteridade das subjetividades, da autossignificação no processo de socialização do seu mundo frente ao precipício do fim que é antecipado narrativamente com tragédias, inclusive, com a maior delas: a morte anônima, não solidária. Estas expressões literárias se manifestam na periferia da sociedade, da vida, do homem comum. É a arte periférica que denuncia o estético comercial e o oficial. Por meio de Benjamin, é possível perceber que a arte de Kafka representa uma luta do humano por descobrir-se a si mesmo no duelo contra o destino que o leva à sua despersonificação, à sua não-humanidade. 
Levando isso às últimas consequências por Paul Ricoeur, as narrativas orais ou escritas são as reservas significativas das identidades. Nelas encontramos a fonte alimentar das ipseidades, das pessoas fáticas ou contingentes. A narrativa, assim, é a dimensão constituinte das personalidades (identidades) e das conexões intersubjetivas situadas sempre nas teias linguístico-sociais. A dimensão arquetípica presente nas narrativas não sufoca ou interdita plenamente a ação - ela não é o destino do ser. Ao contrário, dá à ação contingente do indivíduo o palco histórico e significativo (RICOEUR, 1991, p. 167-198). A literatura de Franz Kafka não pode ser entendida vulgarmente como obra de ficção erigida sem qualquer raiz nas imagens semânticas enraizadas na existência histórica. Por isso, pode-se entender imediatamente que a literatura kafkiana é um palco narrativo "de vários" e entre "vários mundos" humanos: uma literatura sobre um universo chamado homem que habita um ambiente cosmopolita e que, por sua vez, sucumbe trágico e escatologicamente a própria individualidade.

De modo preliminar, é importante salientar uma confluência entre dois aspectos na dinâmica cultural entre religião e arte, a saber: entre o sublime/estético e o divino/sagrado. O leitor de Harold Bloom pode lembrar da máxima de Rudolf Otto (2007) sobre o sagrado, quando o crítico literário afirma que para Edmund Burke "a grandeza do objeto sublime provoca tanto deleito quanto terror" (BLOOM, 2011, p. 33). O teor das expressões Estético/Sublimes e Sagradas/Divinas/ Mistérios não são de fáceis tratos. Porém, é possível afirmar que o sublime se alça com ou sem o reconhecimento público o resultado de sua expressão estética. Ao outro, quanto ao teológico, o divino pode ser destacado sem adequações imediatas às imagens ou personalizações de deuses constituídos no imaginário corrente ao seu contexto, por isso, são misteriosas mesmo que sagradas - questão a ser melhor discutida mais adiante.

No espaço estético, as obras literárias de Franz Kafka estão à altura das experiências que, ainda lá nos tempos do empirismo inglês, Edmund Burke chamava de Experiências Sublimes - em contraposição às Experiências de Belo. Ao trazer este conceito de sublime apresentado por Edmund Burke (1755) com o objetivo direto de analisar o teor 
literário das obras de Franz Kafka, buscou-se reconhecer uma forma de percurso desprendida pelo efeito da narração estética como um dos processos de humanização mental do comportamento humano. A criação sublime abre uma condição na qual o leitor não se sente confortado por meio de expressões que apaziguem as atividades intelectuais por efeito de manifestações consensuais de beleza.

O sublime provoca sensações contrárias ao belo. Pela expressão sublime, se procura uma experiência significativa que traga à consciência, uma dimensão esquecida, desconhecida, demasiadamente humana ou profundamente interditada no processo histórico cultural. Por isso, uma obra de arte que desperte no seu leitor a sensação mais trágica ou mais humana, é aquela que está germinando de dimensões iminentemente existentes.

Nas épocas e nas condições de sua escrituralidade autógrafa, é possível que os leitores de Franz Kafka hipoteticamente não atentem para as suas próprias condutas existenciais, simples e banais, por força de uma forte confiança na ordenação não participativa das dimensões econômicas, políticas e jurídico-sociais. Na crítica contida no pensamento narrativo-literário que Kafka alçou às dimensões teológico-negativas e sublimes, buscou-se fundamentalmente revelar o absurdo da apatia humana à sua vitalidade, à sua dimensão mais fundamental (CONCEIÇÃO, 2013). O absurdo social e o fim dramático das contingências, dos personagens não-heroicos, o humano demasiadamente humano, são os motivos narrativos mais fortes nas obras de Kafka. O Artista da Fome é uma obra que denuncia a apatia à vida como algo escatológico, ou seja, como um sintoma do término fático de qualquer futuro humano. Antecipá-lo literariamente é pôr ao homem e à mulher as possibilidades de ir além da imanência escatológica - fruto do cotidiano em esteiras do progresso que promete emancipação, mas só revela barbárie. Uma literatura sobre a singularidade humana como motivo critico à teleologia do progresso social, sobre uma história negativa, busca-se uma redenção presente em cada humano de modo que as pessoas possam reinventar a vida. 


\section{A face misteriosa e abscôndita do religioso no mundo intelectual e na literatura kafkiana}

Franz Kafka ao lado de intelectuais como Ernest Bloch, György Lukacs, Walter Benjamin, Martin Buber, Franz Rosenzweig e Gershom Sholem, expõem uma dimensão fundamentalmente comum entre o judaísmo e a erudição estético-filosófica de raízes românticas. Esta intercessão intelectual é capaz de frutificar temas e motivos de pensamento crítico a uma época e suas circunstâncias, exclamando a inversão daquilo que outrora a modernidade iluminista conclamava no advento de seu momento moderno, burguês e capitalista: a liberdade, a fraternidade e a igualdade. Estes pensadores de língua alemã formaram um círculo institucional imanentemente integrado, mas não programado de intelectuais judeus predominantemente da Europa Central (Mitteleuropa). Essa ligação de amizades que antecederam e transcenderam quaisquer ligações institucionais, provocou um compartilhamento nem sempre silencioso de intuições e de sentimentos intelectuais que fizeram surgir um universo cultural entre eles.

Michael Löwy explora o laço dialético cultural entre o espírito do romantismo e um tipo de misticismo judaico que parece apoiar intelectualmente as rupturas desprendidas por vários pensadores no século XX - o século do progresso desprendido e inquestionado. Esses pensadores considerados heréticos para com a tradição rabínica e insatisfeitos com o iluminismo político, econômico e técnico-científico, inclinaram-se em direção a uma nova concepção da história. Para intelectuais como Franz Kafka, o tempo e o mundo vivido se desvencilhavam de suas máscaras evolucionistas ou do progresso. Para ele, a antropologia literária relevava um homem em tensão que a antropologia econômica e política confinava à produtividade. A categoria "afinidade eletiva" proposta por Michael Löwy é uma tentativa de compreender a dimensionalidade cultural da intelectualidade judaica da Europa central, que exercitou reflexões filosóficas, religiosas, literárias etc., em meio a diversos ajustamentos entre três impulsos: a "utopia romântica", a "escatologia" e o "messianismo restitucionista". Trata-se de procurar, segundo o Löwy, 
reconstituir, em sua unidade pluridimensional, todo um universo cultural socialmente condicionado. Tal abordagem procura iluminar, sob um novo ângulo, uma vasta parcela da cultura europeia moderna, detectando uma rede subterrânea de correspondências que liga entre si alguns de seus espíritos mais criadores ${ }^{2}$.

Dessa feita, algumas categorias da tradição teológico-judaica são fundamentais para entendermos um panorama do pensamento judaico do qual Franz Kafka compartilhava:

- Et Ketz - expressão que revela um instante final, de destruição, condição inicial para se instaurar uma restauração plena). Esta é uma expressão escatológica. Seu uso indica a total impossibilidade de qualquer redenção a partir das condições ordinárias do real. O fim do sentido, da vida e do mundo, nas dimensões subjetiva, social e cósmica, demandam um ceticismo nas ordens imanentemente estabelecidas, ou seja, um pessimismo definitivo para com quaisquer possibilidades hipoteticamente dirigidas a uma melhora ou restauração a fim de contornar as possíveis experiências negativas. O Et Ketz é um desejo ou uma expectativa de antecipação do fim que se anuncia incontornavelmente, mas expressa, também, uma esperança na redenção plena de caráter absoluto e radical.

- Shevirat Há-Kelin - expressão "quebra dos vasos" que aponta para um determinado momento na história do universo em que se tem o cessamento da harmonia original instaurada imediatamente após a criação). Esta expressão, que é tardia no judaísmo e muito presente nos ensinamentos hassídicos, indica o rompimento da harmonia original na realidade criada. Na ordem da criação, este evento seria mais primordial para explicação do advento sócio-natural do mal do que aquele interpretado e apresentado pela fé cristã - na qual justifica a desconciliação plena pelo dogma do "pecado original" construído a partir de uma interpretação teológica do evento transgressivo de Adão e Eva e da consequente expulsão de ambos do paraíso.

- Olam Ha-Tikkoun - expressão em hebraico para a ideia de reconciliação de tudo). Esta expressão traduz a esperança pelo Tikkoun (redenção), por consequência dos desencadeamentos de eventos rotineiros, da

2 Idem. 
história, desprendidos pela força continuamente progressiva do desordenamento (Shevirat Há-Kelin). Da teologia judaica para a história social, esta expressão foi acolhida nos dias em que os judeus se ressentiram socialmente como vítimas e marginalizados das excludentes e perversas políticas nacionalistas.

Estas expressões nem sempre estão explícitas na literatura do pensamento literário ou filosófico dos pensadores romântico-judeus. Delas, eles apreciaram intelectualmente (nas artes, na filosofia, nas ciências da história social e das religiões, na teologia etc.) o sentimento crítico e fatalista da história (Geschichte) por resultado dessas experiências. Em meio a esta imanência social, política e econômica, suas individualidades foram vencidas por uma História enaltecida, segundo a cultura ocidental, como ápice da expressão do progresso total.

As obras de Franz Kafka são uma advertência à sublimação da vida humanamente significada. Por isso, seus desafios transformam seus personagens em ícones da perseguição, seus tolhimentos subjetivos tornaram-se em problemas de afirmação das singularidades, seus desejos de reconhecimento ganharam a problematização ética da alteridade e suas esperanças mais sublimes foram transformadas numa linguagem para além das fronteiras semitas: a redenção emancipativa (Tikkoun no hebraico, Erlössen em alemão) de todos num estado de reconciliação plena - reconciliação desejada e ingenuamente pensada num mundo hostilmente real.

Walter Benjamin (1994, p. 153) já advertiu que as recepções da literatura kafkaniana por meio de uma psicanálise ou por uma teologia de lugares comuns, vão mascarar comodamente as sinuosas narrativas de um escritor que não se volta às dimensões ideológicas, mas à dimensão originariamente humana. Do ponto de vista religioso, a literatura de Franz Kafka traz consigo as expressões de atos teológicos negativos, proféticos e escatológicos. Isso porque agora o nada, o não-ser, é condição presente à vida e não mais algo contido na necessidade lógica de se justificar a existência de uma divindade absoluta. É na antropologia fundamental que se tece a vivencialidade, e é sobre ela que se falsifica a sistematicidade do poder ou da ordem des-vitalizante. Sobre este tempo intelectual e teológico 
deste primeiro século, momento que evoca algumas experiências intelectuais como as do existencialismo, afirma Tillich,

O existencialismo recente 'encontrou-se com o nada' (Kuhn) de uma forma profunda e radical. De certa maneira, ele substituiu o ser-em-si pelo não-ser, atribuindo ao não-ser uma positividade e um poder que contradizem o sentido imediato da palavra. O 'nada aniquilador'de Heidegger descreve a situação do ser humano ameaçado pelo não-ser de uma forma ultimamente inevitável, isto é, pela morte (TILLICH, 2005, p. 198).

A categoria de sublime ainda não completaria os estudos interpretativos das obras de Franz Kafka se o leitor não alcançasse a dimensão mais fundamental do sentido da vida: a dimensão teológica, a dimensão da reflexão divina. Em sua obra organizada tardiamente sob o nome A Metafísica, Aristóteles trata dentre vários temas o de Deus e do Pensamento Divino. Aristóteles faz uma distinção epistemologicamente sagaz entre o pensamento divino e as personalidades divinas. Ao pensamento divino, Aristóteles atribui-lhe o status de uma faculdade do pensamento humano. Sem entrar no mérito onto-teológico da relação entre ato puro e existência material do conteúdo pensado teologicamente, Aristóteles põe o Pensamento Divino como o ato que pensa o fundamento da totalidade, da dimensão arquetípica de tudo. A busca pela unidade correlativa entre todos os entes do universo faz com que a prima filosofia fosse uma disposição conceitual da qual o ser humano busca os "primeiros princípios", quer da natureza, das essências particulares dos entes da natureza, do Bem ou quer do Belo. O pensamento divino busca "o princípio a que estão subordinados os céus e toda a natureza" (ARISTÓTELES, 1969, XIII, 7, 15, p. 258). Este pensamento não nasce na filosofia e nem em sua obra. Aristóteles sabe bem que essa cavalgada especulativa já era distintiva nos mitos e, por isso, praticada rotineiramente entre os humanos narrando, refletindo ou ouvindo.

Nicolau de Cusa (VANINI, 1996, p. 284-288) apresenta a Teologia Negativa como possibilidade de abertura à supremacia, inclusive ininteligível de Deus, ou seja, pensar a supremacia divina sem reduzi-la aos contornos predicáveis apropriados à qualificação, quantificação, modulação e relação de coisas próprias da natureza criada. Para Tillich (p. 197), esta 
forma de reflexão teológica propôs a Deus uma infinitude não predicativa de modo que Ele, o Ser Primeiro em Si-Mesmo, é, inclusive, portador de negatividades (mal, pecado, etc.), mas sempre ordenado num sistema dialético que não fragiliza a sua Soberania Fundamental. Mas, a descontinuação entre ação ontologizante e realidade significada em Immanuel Kant, impôs uma cisão na contínua identidade entre ser, pensar, realidade prima e a natureza mundana. Assim, pensar teologicamente após Kant (sem menosprezar a importância do pensamento dialético e de proporções cosmológicas de Hegel e Schelling) passou a representar a destinação do ser humano à condução de uma vida com intensa significação a partir e sob os limites de sua factualidade. Por isso, afirma Essen (2010, p. 201), que

A transformação, encaminhada fundamentalmente por Kant, da metafísica da alma em teoria do sujeito andou de mãos dadas com uma crítica radical à psicologia racional e tradicional e, em decorrência, teve de ser percebida como destruição do conceito tradicional de alma. Atingidos por ela, contudo, foram praticamente todos os tratados dogmáticos nos quais o conceito de alma tinha importância central, mais particularmente a antropologia teológica e a escatologia.

Se a persistência teológica não encontrou ecos numa ontologia personalista de um deus soberano e pessoal, nem por isso o pensamento humano abdicou da ação reflexiva divina. Os sobressaltos às principialidades da natureza, da vida e da humanidade, não cessaram no pensamento. O Eclipse de Deus após a decadência da metafísica tomista não inibiu a prática de se buscar o divino, um divino acima de Deus (TILLICH, 2005), um ser-humano para além do humano hodierno - nos melhores dizeres de Niezsche, um Übermenschen.

A desconstrução de uma visão ontológica ajustada do mundo é um importante marco intelectual nos tempos de Franz Kafka. Eis a sua nova tipologia de sua cosmologia ou teologia escatológica: e negatividade como dimensão suprema da existência. A negatividade teológica é positivamente saudada pelo escritor tcheco. As trajetórias dos personagens de Franz Kafka amargam continuamente o fim, o escatológico. Para um leitor persistente e incomodado com a vida, sabe que o fim não precisa ganhar um 
contorno cataclísmico na natureza para que se realize em sua plenitude. O fim pode perpassar pela morte ou pelo o esquecimento que o ser humano vivencia à luz do dia na socialização, na indiferença pública. Numa sociedade em que o ser humano contingente, singular, não é fundamental, a vida e a morte não espantam mais a ninguém. Eis a reação escatológica da literatura kafkaniana: antecipar o fim para que emerja na consciência a importância da redenção da vida, da existência. A apatia deve ser tragada por uma obra de arte que assuste o ser humano por aquilo que lhe é mais impactante: o sublime e o divino - mesmo que em aspectos antropocêntricos. A arte escatológica não tem um fim político em Franz Kafka. É muito mais que isso. Ela tem um fim primitivo à política, à economia, etc. Ela vem e volta redentoramente ao humano que se cria, se redime. Daí, por consequência, renova toda a sua culturalidade - e, em macro dimensões, a sua sociabilidade.

O negativo sozinho, por mais forte que seja, não é o bastante, como eu chego a pensar em meus momentos de maior desconsolo. Pois sempre que dou um mínimo passo acima, sempre que conquisto algum sentido de segurança, mesmo o mais dúbio, eu então me demoro e espero pelo negativo, não para que venha até mim, mas para me puxar para baixo. Trata-se portanto de um instinto de defesa, que me impede de gozar um conforto duradouro, por menor que seja, e desfaz a cama matrimonial, por exemplo, antes mesmo de ter sido feita (KAFKA, 1998).

\section{"O Artista da Fome"}

Hannah Arendt escreveu em 1968 como parte da introdução de sua obra Homens em tempos sombrios (2008, p. 09), a seguinte uma expressão que serve como estofo para leituras das obras de Franz Kafka - mesmo que não o tenha como alvo de suas análises posteriores:

Os 'tempos sombrios', no sentido mais amplo que aqui proponho, não são idênticos às monstruosidades desse século, que de fato constituem uma terrível novidade. Os tempos sombrios, pelo contrário, não só não são novos, como não constituem uma raridade na história, embora fossem 
desconhecidos na história americana, que por outro lado tem a sua bela parcela, passada e presente, de crimes e catástrofes. Que mesmo no tempo mais sombrio temos o direito de esperar alguma iluminação, e que tal iluminação pode bem provir, menos das teorias e conceitos, e mais da luz incerta, bruxuleante e frequentemente fraca que alguns homens e mulheres, nas suas vidas e obras, farão brilhar em quase todas as circunstancias e irradiarão pelo tempo que lhes foi dado na terra.

O paradoxo entre a "singularidade da existência" e o "totalitarismo da sociedade constituída" é um dos tinos fundamentais dos escritos de Franz Kafka. É um aceno parcialmente positivo às teses freudianas desenvolvidas na obra Mal-Estar da Civilização, mas, exposta aos contextos dos indivíduos e de suas emergentes sociedades burguesas da Europa liberal. Por isso, suas literaturas narrativas que expõem as fraturas da vida, anunciam escatologicamente que incêndios entre os humanos, são amostragens dos estorvos para o desdobramento de vidas em suas possíveis plenitudes. O Artista da Fome (Ein Hungerkünstler) é um conto publicado pela primeira vez em 1924 na revista literária Die Neue Rundschau. A década de 20 e de 30, do século XX, foi marcada por uma grande crise econômica e social nos países de fala alemã e não mesmo no mundo ocidental de economia capitalista. Em seu filme "O Ovo da Serpente" (BERGMAN, 1977), Ingmar Bergman mostra o momento social da política liberal do Estado de Weimar. O Zeitgeist que o filme reconstrói é marcado pela miséria da fome, do vácuo político, do medo, de ações impessoais de ciência, etc. Mutatis mutandis, esse era o cenário que marcava o contexto do conto de Franz Kafka, esse era o contexto que justificava a falta de interesse pelos últimos dias do Artista da Fome (Hungerkünstler). Em 1880, o médico americano Henry Tanne fez desafios do uso da fome para mostrar os benefícios para a saúde humana da sua fórmula dietética radical à base de água. Esta dieta, que tinha sido recomendada para benefícios biológicos e para o ensino de questões morais (controle da vontade, etc.), passou a ser usada como espetáculos por vários artistas na Europa.

Franz Kafka afirma em seu conto que a arte da fome divertia os adultos mas surpreendia as crianças. Vendo esta cena de forma lúdica, do ponto de vista daquilo que Claude Levi-Strauss chama de 
pensamento concreto, e da teoria do desenvolvimento cognitivo de Jean Piaget: arte da fome surpreendia as crianças porque elas associam o mundo que as contornam diretamente aos seus corpos, às suas vidas. Para o público infantil, a arte da fome as arrebatava à vida do artista e, por isso, o efeito era o "assombro, de boca aberta, uma segurando a mão da outra por insegurança” (KAFKA, 1998, p. 25). Por dimensão realista, a arte da vida exposta ao limite da morte pela fome, surpreendia as crianças; por um absurdo, a arte divertia os adultos. Contudo, os tempos mudaram. Nos tempos de publicação do conto, a fome era rotineira. Ninguém mais se surpreendia por algo partilhado por tantas famílias populares e que ameaçava aqueles mais abastados. Poucos ainda poderiam se dedicar ao gasto com espetáculos. Mas, espetáculos sobre a vida rotineira, sobre a fome, a miséria, a violência, não seriam mais espetáculos e sim notícias.

A arte da fome era mais que um espetáculo. Aos moldes do que foi apresentado por um dos seus divulgadores, o médico Henry Tanne, o espetáculo da dieta por ingestão exclusiva de água, era um desfio. Por isso, mesmo diante a muitas fraudes, o artista da fome tinha uma honra. Para dar garantias das regras do espetáculo, os empresários disponibilizavam iluminações e vigias em torno do artista. O artista determinado em cumprir os ofícios inclusive empregatício de sua arte, desenvolve uma forma de vida que implicava na abstinência de alimentos, adaptação de um humor vital para garantir a sua sobrevivência, uma relação interambiental desde seu espaço de reclusão, etc. Mesmo diante a todas essas circunstancias, o público não amenizava as suas desconfianças para com a sinceridade da fome. No final das contas, "só ele sabia - só ele e nenhum outro iniciado - como era fácil jejuar" (KAFKA, 1998, p. 26). Por isso, ficava inconformado com a falta de crédito pleno por parte do público, mesmo com tanto espetáculo no final dos quarenta dias - limite estabelecidos para a execução pública do evento. Na saída, o artista é personagem de um negócio lucrativo. O empresário vai ao seu encontro não como algo interativo, mas como algo gerador de lucro, impessoal. Na saída da jaula, o empresário não troca palavras com o artista, apenas toma-lhe a mão num momento do grande espetáculo, do grande negócio. Apesar dos acenos e da festa, 
tudo era impessoal, sem afeto, sem confiança, sem intimidade, sem interpessoalidade. A arte da fome não se revelava mais como um acontecimento sublime das dimensões limítrofes da vida, mas apresentava-se como um negócio; a trama não requeria mais respeito, camaradagem ou familiaridade entre os envolvidos (público, empresário, artista-empregado e contratados), apenas lucro. Todos os embates vividos e que emergiram da fome de quarenta dias não importa. O espetáculo lucrativo é mais importante. As opiniões do artista são silenciadas pelos músicos que tocam em volumes altíssimos. A fome e a existência são sublimadas pelo espetáculo lucrativo. Esquecido das reflexões mais profundas nos dias de confinamento, o autor está inebriado com a fama e a sua luta é por convencer a todos que poderia permanecer por mais dias. A arte e o pensamento reflexivo são absorvidos pela festa de entretenimento.

Assim viveu muitos anos, com pequenas pausas regulares de descanso, num esplendor aparente, respeitado pelo mundo mas, apesar disso, a maior parte do tempo num estado de humor melancólico, que se tornava cada vez mais sombrio porque ninguém conseguia levá-lo a sério. Aliás, com o que poderia ser consolado? O que lhe restava desejar? E se alguma vez uma pessoa bem-intencionista se compadecia dele e queria lhe explicar que sua tristeza provavelmente vinha da fome, podia acontecer - em especial no estágio avançado do jejum - que respondesse com um acesso de fúria e começasse a sacudir as grades como um animal, para susto de todos. Mas para esses estados o empresário dispunha de um castigo que gostava de aplicar. Desculpava o artista perante o público reunido, admitia que só a irritabilidade provocada pelo jejum - facilmente compreensível por pessoas bem alimentadas - tornava perdoável o comportamento do jejuador; nesse contexto acabava se referindo também à afirmação do artista da fome - igualmente merecedora de um esclarecimento - de que poderia jejuar muito mais ainda do que jejuava; elogiava a elevada ambição, a boa vontade, a grande negação de si mesmo que sem dúvida estavam contidas nessa afirmação, mas depois procurava refutá-la, pura e simplesmente, mostrando fotografias - que eram vendidas naquela hora - pois na imagem se via o artista da fome, no quadragésimo dia de jejum, quase extinto de inanição. Essa distorção da verdade, de resto bem conhecida, mas sempre enervante, era demais para o jejuador. O que era consequência do encerramento prematuro do 
jejum se apresentava aqui como sua causa! Era impossível lutar contra essa incompreensão, contra esse mundo de insensatez. Embora sempre tivesse ouvido de boa-fé o empresário, quando as fotografias apareciam ele largava das grades da janela, às quais estivera ansiosamente grudado, e afundava outra vez na palha, soluçando; e então o público, acalmado, podia aproximar-se e examiná-lo (KAFKA, 1998, p. 29-30).

Como todo negócio que apresenta produtos com validades efêmeras e pertinências com datas de validade limitadas a um curto espaço de tempo, o negócio "artista da fome" foi perdendo seu fôlego a não despertar mais interesse no público pagante. "Seja como for o mimado artista da fome se viu um dia abandonado pela multidão ávida de diversão que preferia afluir a outros espetáculos" (Idem, p. 30). Entre idas e vindas, o empresário buscava algum espaço social lucrativo. Mas, a persistência era em vão. Não havia qualquer possibilidade de público e lucro. Em meio à crise, o artista relembrou de muitas ideias que teve sobre a sua condição, sua arte, sobre a vida, sobre a sua sorte, mas que as abandonou nos tempos da fama ébria. A força do seu sucesso suplantou por decisões do próprio artista, as suas mais íntimas e sinceras reflexões sobre a vida. Porém, a vida estava em dinâmica. O Artista envelheceu, não tinha mais um público para enaltecer a sua arte e a fome ainda lhe pertencia como uma obsessão de vida pela fama e pela vontade de superação dos limites do corpo.

Sem alternativas, o Artista da Fome abriu mão do seu empreendimento artístico-comercial, quase que aos moldes artesanais, e agregou-se ao um empreendimento maior: o circo. Em nome da segurança, abriu mão de sua pouca autonomia empreendedora para se agregar ao circo.

Quando as testemunhas se recordavam dessas cenas, alguns anos mais tarde, muitas vezes não compreendiam a si mesmas. Pois nesse meio tempo interveio a virada já referida; isso aconteceu quase de repente; devia haver motivos mais profundos, mas quem iria se preocupar em descobri-los? Seja como for, o mimado artista da fome se viu um dia abandonado pela multidão ávida de diversão que preferia afluir a outros espetáculos. O empresário percorreu novamente com ele meia Europa para ver se aqui e ali não se reencontrava o antigo 
interesse; tudo inútil; como se fosse por um acordo secreto, em toda parte havia se estabelecido uma repulsa contra o espetáculo da fome. É evidente que na realidade isso não poderia ter sucedido de repente e recordava-se agora, com atraso, de muitos presságios que na época da embriaguez do triunfo não tinham sido suficientemente respeitados, nem suficientemente reprimidos; mas agora já era tarde demais para fazer alguma coisa. Certamente os bons tempos do jejum um dia também voltariam, mas para os que viviam naquela época isso não era um consolo. O que o artista da fome podia então fazer? Quem tinha sido aclamado por milhares de pessoas não podia exibir-se em barracas nas pequenas feiras, e para adotar outra profissão o artista estava não só muito velho, mas sobretudo entregue com demasiado fanatismo ao jejum. Sendo assim, demitiu o empresário, companheiro de uma carreira incomparável, e se empregou num grande circo; para poupar a própria suscetibilidade, nem olhou as condições do contrato.

Um grande circo, com seus inúmero homens, animais e aparelhos que sem cessar se recompõem e se completam, pode utilizar qualquer um a qualquer hora, mesmo um artista da fome - naturalmente se as pretensões dele forem modestas; além disso, neste caso particular não era apenas o próprio jejuador a ser engajado, mas também o seu nome antigo e famoso; de fato não se podia dizer, dada a peculiaridade da sua arte - que com o avanço da sua idade não diminuía - que o veterano artista, passado o auge da sua capacidade, queria se refugiar num posto tranquilo do circo; pelo contrário, o artista da fome garantia que jejuava tão bem quanto antes, o que era perfeitamente digno de fé; afirmavam até que, se o deixassem fazer sua vontade - e isso lhe prometeram logo - desta vez ia encher o mundo de justificado espanto; uma declaração, contudo, que só provocou um sorriso nos especialistas, cientes do espírito da época que, no seu zelo, o artista da fome facilmente esquecia (Idem, p. 30-31).

No circo, o Artista da Fome passou a ser um entre várias exposições que ganhavam atenção nos intervalos dos espetáculos. Porém, o seu show circense não tinha a antiga exclusividade. Agora, era apenas uma mostra exótica entre as dos animais - que eram as mais procuradas pelo público. Não havia mais o susto, a admiração, o diálogo intenso de olhares entre o Artista da Fome e o púbico. A apresentação do Artista da Fome era mais superficial que a anterior. A sua fome já não causava mais espanto. Os espectadores não sentiam mais a fome 
do Artista. O fim se aproximou. Não é necessário que haja um evento catastrófico, uma hecatombe, para que o fim se anuncie como algo teleológico à lógica de sociabilidade vigente. O fim do sentido da vida é a dimensão terminal mais terrível a um indivíduo: a sua escatologia! A jaula, os cartazes que anunciavam a proeza do Artista da Fome era um embuste, uma farsa ao talento do artista. Aquela situação fraudava o seu talento, a sua expressividade artística, por consequente, vital. Não haveria desague se não este: "Passaram-se ainda muitos dias e até isso chegou ao fim" (Idem, p. 34).

Naquela arte da fome, não havia mais testemunhas, vigias, imprensa, atenção. O corpo do artista definhava com a sua fama, e a repercussão de seu feito estava enjaulada num passado silencioso. Passaram-se dias e ninguém mais sabia qual espetáculo acontecia naquela jaula. Um inspetor perguntou aos serventes sobre qual a função daquela jaula que tinha apenas palhas apodrecidas no chão. Um dos serventes lembrou-se do artista. Remexeram as palhas e encontraram o homem faminto, esvanecendo à mingua, à fome, ao esquecimento. Sob os olhares do inspetor, ele ouviu a pergunta que o inquiria sobre até quando iria permanecer sem comer. Sob a imagem teatral encenada textualmente por Kafka, o artista esfomeado de vida e comida, definhado numa cela ao chão, camuflado por palhas apodrecidas, dialoga com o inspetor em posição altiva. No diálogo o artista sussurra e o inspetor impõe um tom de voz inquisitivo e com uma posição tal que não esboçava qualquer ação de compaixão ou solidariedade para com o seu outro.

A cena final é escatológica e de profundas cisões sócio-vitais. O diálogo entre o inspetor e o artista era hierárquica e sem qualquer intersubjetividade, interação, intercompreensão, vivência comunitária. A disfarçastes de solidariedade e atenção que o inspetor esboçava ao artista era de que tinha a autoridade ordenadora, mas que não tinha qualquer solidariedade para com a precariedade vivida pelo artista. Do outro lado, o artista esforçava-se para se expressar intimamente ao inspetor e dizer a ele profundas confissões vitais. O Artista da Fome se desculpou por aquele momento. Deveriam desculpá-lo pela fome artística. O espetáculo que ele expunha não era mais sincero. Não vinha 
de quem queria superar os limites de dieta tão árida em alimentos. Os motivos eram heterodoxos ao ofício. A opção pela fome tinha motivos críticos, profundamente significativos: "porque eu não pude encontrar o alimento que me agrada. Se eu o tivesse encontrado, pode acreditar, não teria feito nenhum alarde e me empanturrado como você e todo mundo" (KAFKA, p. 35). Estas foram as últimas palavras escatológicas do artista. Ela não anuncia a morte dele mesmo, mas do sentido da vida significada, mental, existencial. Se a mística judaica anuncia a criação do mundo como ato fundamentado na ontologia da linguagem, logo, no seu primeiro ato, o Aleph, a vida acaba após o desordenamento e caoticidade dos mais profundos sentidos vitais. Após estas palavras, o artista morre e a dignidade de sua vida é vazia e o seu ato mortuário é apático e submetido à limpeza das palhas apodrecidas da jaula. A morte do artista, a sua memória e a experiência tecida nos rumos de sua vida passam a ser um peso social, um dejeto apodrecido, um contrapeso à vida comercial e fúlgida do entretenimento comercial-circense. A sabedoria desvanece, a vida cessa... a dinâmica e o imperativo mecânico-comercial seguem historicamente como uma tempestade que nem mesmo os anjos conseguem domá-la. As sabedorias, narrativas, os intimismos humanos não são mais os sujeitos de uma história que amorfa surdamente às consciências singulares de homens e mulheres.

$\mathrm{Na}$ primeira parte do artigo, provocou-se a ideia de que a literatura de Kafka não emerge do epicentro sócio cultural de seu mundo, mas da periferia. A expressão artístico-literária não se remonta a heróis ou heroínas dos panteões gregos ou cristãos, mas à insuportável condição desnuda do ser humano normal. Ainda mais, é partir da segunda e da terceira parte das nossas referências teóricas expostas neste artigo que podemos entender a literatura de Kafka como uma sublimidade criativa a qual resgata o escatologismo religioso do misticismo judaico e, ao mesmo tempo, a criticidade iluminista: pense e sinta o mundo a partir de sua autonomia, de sua facticidade humana. Assim, o que se expõe são os limites e as possibilidades de uma existência reflexiva adormecida, por isso, aporética para a existência da humanidade. Esta latência, contudo, é cara, pois sua fatalidade autodestrutiva é o germe de uma dialética negativa pontual no processo de socialização 
iminente. A desconciliação cabalística é o fio condutor desta socialização autômata: é o princípio de sua apocalíptica. Nestes termos, afirma Löwy, que "a finidade eletiva entre teologia negativa e utopia negativa constitui, provavelmente, um dos componentes essenciais da qualidade espiritual enigmática e singular dos escritos de Kafka (LÖWY, 2005, p. 133)". Kafka retraz em seu personagem O Artista da Fome a qualidade negativa da teleologia da socialização emergente, ou, mais especificamente, uma socialização que não suporta as perguntas trazidas à consciência literária as quais tratam pela significância da vida, aquela mesma que incomoda todas as dinâmicas e as rotinas do dia a dia da sociedade até então julgada como racional e civilizada. O que o Artista da Fome revela é que o esclarecimento burguês foi soterrado pelo seu próprio projeto iluminista e, que em seus passos rotineiros, segue-se na direção da autodestruição e do obscurantismo. Não há mais desejo e nem vontade pelo belo, justo e bom conscientes.

A política e o direito contemporâneo que se ajustam pelo ideal de justiça prevalecem pela dialética entre liberdade fundamental e solidariedade republicana. A literatura de Kafka expõe a fragmentação da sociabilidade política e jurídica de seu tempo. A individualidade se expõe como enclausurada ideologicamente ao ponto de seu comportamento não ser mais capaz de aprofundar suas ações a partir de reflexões críticas e de profundo significado vital. O sujeito moderno abriu de sua subjetividade no momento em que o autoritarismo do mercado, da política partidária ou das tradições aristocráticas lhe impuseram conduções e condições de vida sem depender de qualquer deliberação pessoal. A morte do Artista da Fome é a mesma de Samsa: a morte da consciência que não quer se sujeitar à transitoriedade e ao instante fugaz da ideologia e da mortalidade da vida. Por isso, a literatura de Kafka antecipa o fim: com o estabelecimento do fim escatológico, absoluto, há uma centelha de esperança na redenção de todas as coisas, uma esperança contra a história. 


\section{Considerações finais}

O Fim do Artista da Fome revela uma obra aos moldes dos antigos profetas bíblicos do século VII a.C.: os negócios definham a arte, a lógica de socialização teologicamente comercial, ao menos aquelas que se impulsionam aos moldes capitalistas, aquelas que em nome da produção e da riqueza apontam um ideal soteriológico, definham a vida. À analogia com os textos profético-hebráicos do cânone Tanac, o Artista da Fome de Kafka pode ser posto como uma imersão literária ao fato, a conflitos rotineiros, à concretude vivenciada e às crises remexidas pelas subjetividades conflituosamente vividas: essa é a dimensão negativa com a qual Kafka luta, contra a positividade incondicional da lei e do ordenamento oficial, contra os contos heroicos dos mortos que sublimam as dores, a destruição e a vacuidade vivida pelos que ainda existem. Das macroeconomias, dos ordenamentos internacionais da política global, o Artista da Fome traz à experiência narrada e trágica, a vida singular. A vida que reflete, que é o fundamento elementar das sociedades totalitárias ou democráticas, mas, é aquela que pode ser fugazmente esquecida, banalizada.

As narrativas de Franz Kafka não trazem consigo a imagem de heroísmo e nem de histórias vitoriosas. Muito menos suas histórias se desfecham como bálsamos que satisfazem os leitores, os quais esperam no destino o cumprimento da felicidade, de tempos melhores. Kafka luta contra o destino e busca intensamente revelar aos seus leitores a sua negatividade escatológica. Por isso não há heróis e nem super-dramas, e sim aquilo que nenhum ser humano burguês suportaria: o drama da vida comum, sem sentido, no qual a vida definha sem atenção do público pois todos estão voltados ao sucesso de empreendimentos estranhos a si mesmos. Em suas obras, o que se revela é a dramaticidade e a ilusão da felicidade, de festejos, ideários de justiças, imposições leis que são impostas por obsessiva ilusão de plenitude humana, mas que, de fato, estão profundamente esvaziadas de sentido vital. Os seus personagens fazem do mistério, do exílio, do sofrimento, etc., meios para que o leitor busque aquilo que outrora foi esmaga pelas janelas de aço de uma sociedade fria e capitalista: a vida e a capacidade humana 
de criação, de autonomia emancipativa contra a história, contra o destino escatológico teleologizado pelo advento do pecado original, pela desconcilização do mundo, pelo domínio de tudo que implica na perda de si mesmo.

\section{Referências}

ARENDT, H. Homens em tempos sombrios. São Paulo: Companhia de bolso, 2008. ARISTÓTELES. Obras completas XIII. Rio de Janeiro: Ed. Globo, 1969.

BENJAMIN, W. Magia e técnica, arte e política. Ensaios sobre literatura e história da cultura. São Paulo: Braziliense, 1994. (Obras escolhidas v. 1.)

O OVO DA SERPENTE. Direção de Ingmar Bergman. Alemanha: Rialto Film Dino de Laurentis Corporation (EUA), 1977. [Título original: Das Schlangenei].

CONCEIÇÃO, D. R. Teologias e Literaturas III: Aspectos Religiosos em Machado de Assis. São Paulo: Fonte Editorial, 2013.

ESSEN, G.; MAGNUS, S. (Eds.). Kant e a Teologia. São Paulo: Loyola, 2010.

FREUD, S. O mal-estar na civilização, novas conferências introdutórias à psicanálise e outros textos (1930-1936). São Paulo: Companhia das Letras, 2010.

GAY, P. Freud: Uma vida para o nosso tempo. São Paulo: Companhia das Letras, 2012.

KAFKA, F. Um artista da fome e A construção. São Paulo: Companhia das Letras, 1998.

LÖWY, M. Redenção e utopia: O judaísmo libertário na Europa Central. São Paulo: Companhia das Letras, 1989.

LÖWY, M. Sonhador Insubmisso. Rio de Janeiro: Azogue, 2005.

MANNHEIM, K. Sociologia do Espírito. São Paulo: Perspectiva, 2014.

ROSENZWEIG, F. La Estrela de la Redención. Salamanca: Sígueme, 1997. 
RICOEUR, P. O si-mesmo como um outro. São Paulo: Papirus, 1991.

SCHOLEM, G. O nome de Deus - A Teoria da Linguagem e outros estudos de Cabala e Mística: Judaica III. São Paulo: Perspectiva, 1999.

TILLICH, P. Teologia Sistemática. 5. ed. São Leopoldo: Escola Superior de Teologia/ Editora Sinodal, 2005.

VANINI, M. La teologia mistica. In: OCCHIPINTI, G. Storia della teologia III. Bologna: EDB, 1996.

VERNANT, J-P. Entre Mito e Política. São Paulo: EdUSP, 2001.

Recebido: 30/11/2015

Received: 11/30/2015

Aprovado: 30/05/2016

Approved: 05/30/2016 